УДК 338.48-6:37.014.242:338.48-32(100=162.1)

\title{
POLISH STUDENTS' MOBILITY DURING THEIR ERASMUS SCHOLARSHIP (purposes, expenses, education)
}

\author{
M. Góralewicz-Drozdowska, W. Maciejewski \\ University of Business in Wroctaw \\ Wroctaw, Poland
}

\begin{abstract}
Erasmus is the biggest exchange programme in the world. Almost 3 million students, from 33 European countries, have participated since it started in 1987. Excursions during the Erasmus programme realize an important educational and social issue. Spending an academic semester at the host university gives an experience which is unattainable for ordinary tourists. Students who participate in Erasmus programme become a new European generation which means they have high mobility, can speak foreign languages, are easy to relate to, tolerant and ready for integration.

The authors focus on Polish students and their tourist experience during Erasmus semester. In order to collect the data for Polish students' mobility during their Erasmus scholarship, an Internet survey (Google Docs) was distributed. The survey concerns: directions of tourist excursions, purposes of traveling, means of transport, type of accommodation, travel expenses.

Key words: Erasmus Programme, students' mobility, tourist excursion
\end{abstract}

\section{Introduction}

Celebrating its $25^{\text {th }}$ anniversary in 2012, ERASMUS is the most successful student exchange programme in the world. Almost 3 million students have participated since it started in 1987, as well as over 300000 higher education teachers and other staff since 1997. The annual budget is in excess of 450 million Euro. More than 4000 higher education institutions in 33 countries participate [1].

The average monthly EU grant received by students (including both studies and company placements) is 254 Euro. The average duration of a student exchange is six months. This has remained constant over the last decade [2].

Source: own elaboration based on: http://www.erasmus.org.pl/sites/erasmus.org.pl/files/Erasmus _ statystyki_07-2012.pdf, accessed: 08/09/2012.

In terms of Erasmus development among Polish higher education institutions, Polish students' mobility has been constantly growing since the academic year 1998/99 with 1,5 thousand students which increased 10 times till the academic year 2010/11 to reach 14,2 thousand of Erasmus students (Fig. 2). 

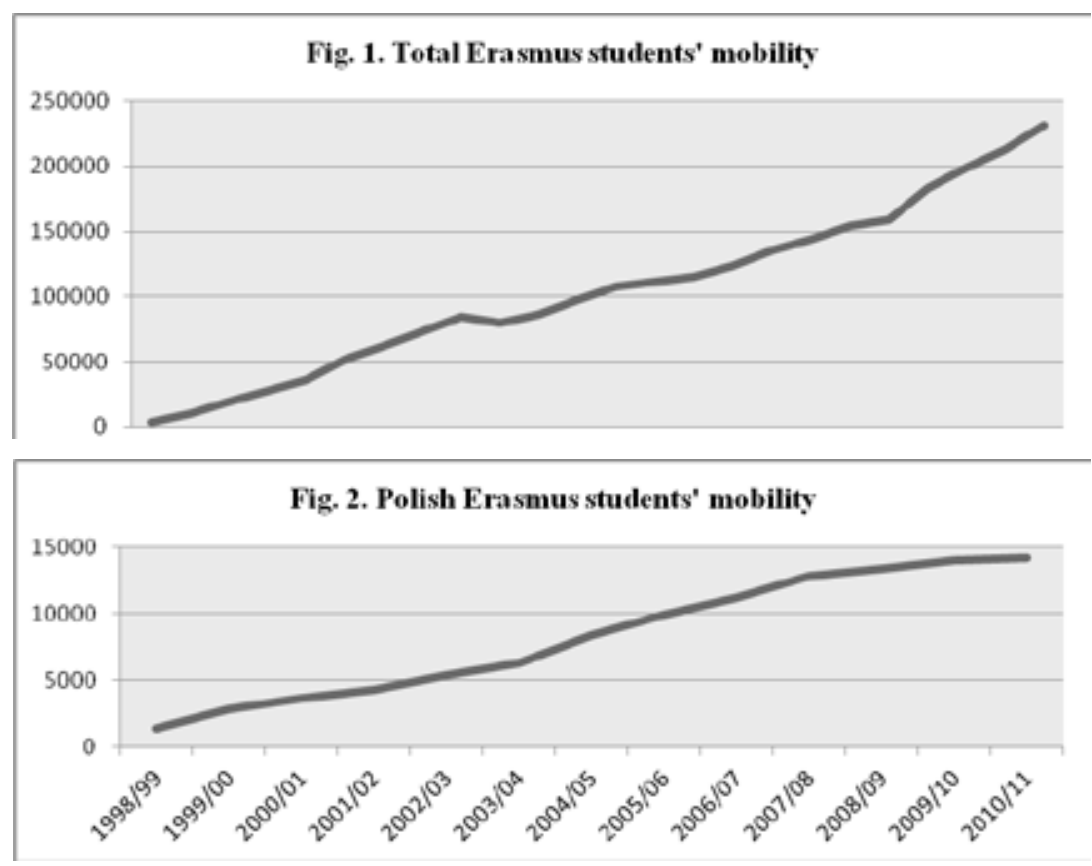

Source: own elaboration based on: http://www.erasmus.org.pl/odnosniki-podstawowe/statystyki, accessed: 08/09/2012.

It is noticeable that $81,5 \%$ of students' travel purposes are connected with studying abroad. Only 18, 5\% decide to participate in company placements with Erasmus. Average duration of the scholarship is 6 months while the internships usually last for 3, 3 months.

The most popular destination among Polish students is Spain, followed by Germany, Italy, France and Romania (Fig. 3). Apart from the education reason students are choosing Germany due to the emigration movement (many Poles work in Germany). Additional reasons could be associated with the close distance to Germany and the fact that Germany is the most important Polish trading partner. Italy and France are very attractive countries because of their history, culture and tourist attractiveness. Spain is popular due to its weather conditions and popularity among other Erasmus students. Romania is one of the cheapest countries in the European Union and it is unevaluated as a tourist destination.

\section{Erasmus students survey - methodology}

In order to collect the data for Polish students' mobility during their Erasmus scholarship, an Internet survey (Google Docs) was distributed. 11572 Erasmus students [3] participated in studies exchange in the academic year 2010/11 and 300 valid responses were received from a random sample of 1500 students (a sample of 2, 6\%). The authors decided to focus just on students who participated in studies in the partner universities because they seem to be much more mobile than students participating in company placement. They get to know local people and their way of life, they have more free time, opportunities and very often strong desire and curiosity to travel. 


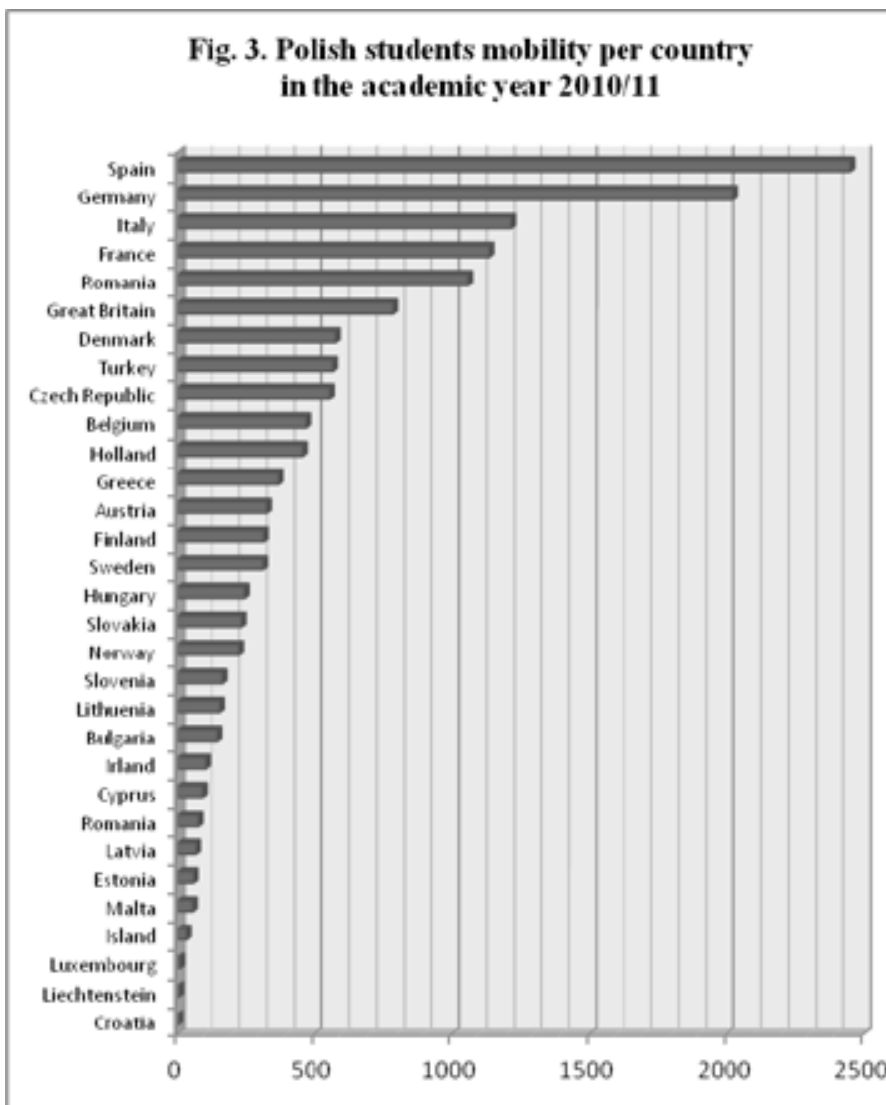

Source: own elaboration based on: http://www.erasmus.org.pl/odnosniki-podstawowe/statystyki, accessed: 08/09/2012.

\section{Erasmus students survey - results}

Erasmus was created as a part of Lifelong Learning Programme. One of its main goals is to improve the quality and increase the volume of students and teaching staff mobility in Europe. The added value of the beneficiaries of the programme is the possibility to get to know local societies, cultures or sites. As the survey shows, most of the students do not limit themselves to visiting the destination of hosting university only; $91 \%$ of them declared to participate in excursions [4] outside their place of scholarship (Fig. 4). Moreover, 56, $5 \%$ of respondents declared to travel outside the country of reference during their Erasmus scholarship (Fig. 5). 


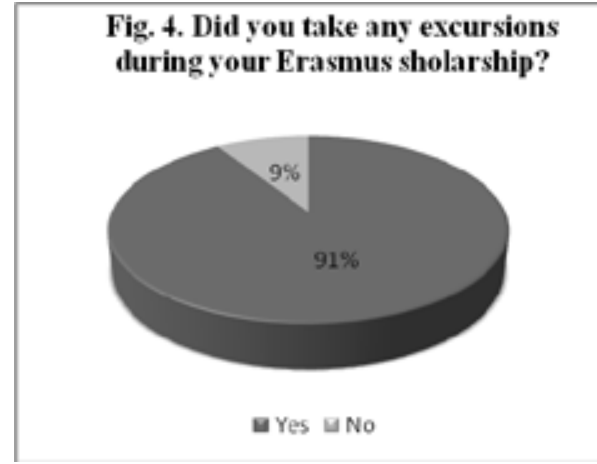

Source: own elaboration.

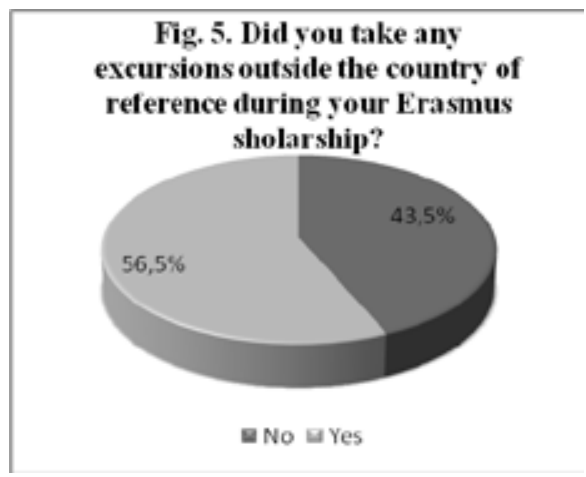

Source: own elaboration.

The most common reason for travelling during Erasmus semester was sightseeing $(93 \%)$ which shows a very strong willingness to learn about and get to know Europe and its diversity better. It is also worth mentioning that $98 \%$ of students declared to take one-day journeys, however, they are not the subject of this research. Very often Erasmus scholarship makes for experiencing the Europe and redoubles future travelling. For many Erasmus students a visit to the hosting university is their first trip abroad.

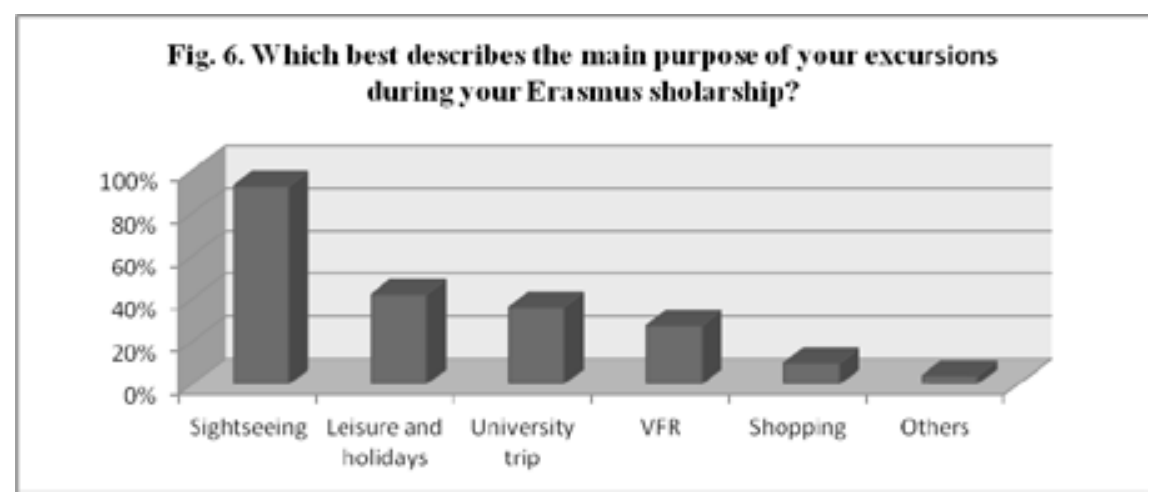

Source: own elaboration.

Sightseeing was the main purpose of Erasmus students' excursions (93\% of respondents). This is a very impressive result which confirms the students want to get to know the country or region of the scholarship better. It is also essential that students have the opportunity to choose the place of hosted university which is basically in their field of interested. $42 \%$ of them decided to travel for leisure and holiday purposes. It is also very common to organize a trip by hosting universities $-36 \%$ of students declared they participated in such an event. Travelling for purposes connected with visiting friends and relatives declared $27 \%$ of respondents. 
Fig. 7. What was your main form(s) of transport during excurtions?

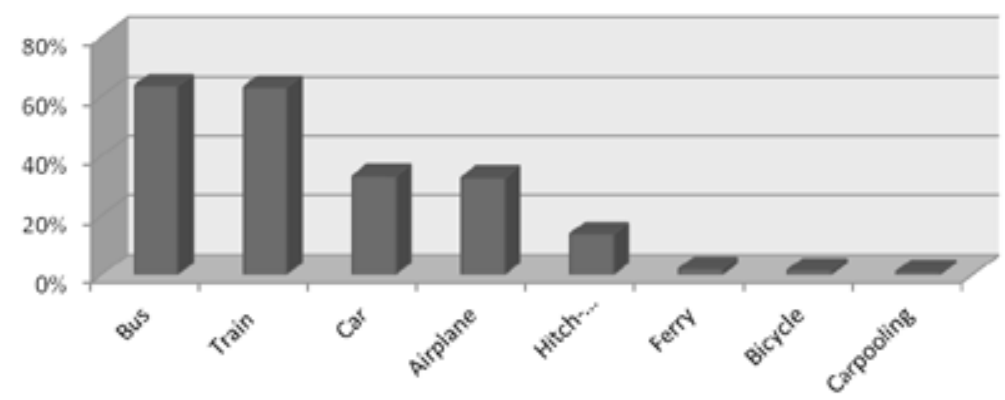

Source: own elaboration.

The countries most often chosen by Polish Erasmus students are ones with good public transport links. When travelling the most popular transport means are buses $(64,4 \%)$ and trains $(62,9 \%)$. Apart from the infrastructure, the high popularity of these transport means is caused by student discount on public transport. A good flight connections resulted in 32, $7 \%$ of interviewed choosing this form of transport. A car was also a popular choice (33, $2 \%$ ) when travelling.

Source: own elaboration.

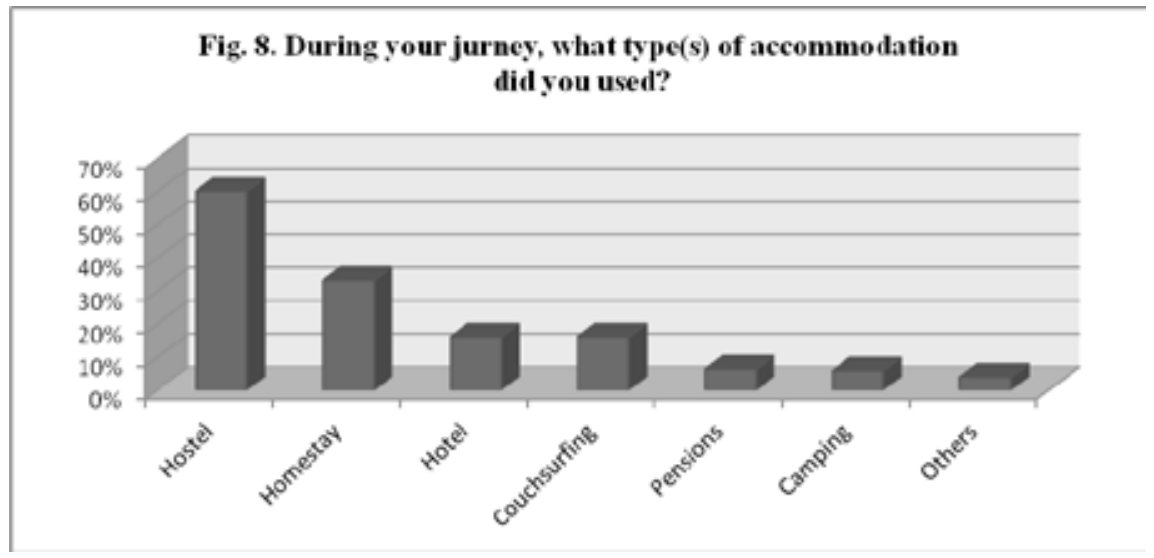

Most of the students $(60 \%)$ decided to stay in a hostel. It tends to be budget-oriented, mainly located in cities and generally more "adventure travel" oriented with opportunities to socialize type of accommodation. It also seems to be the most common among young people. $1 / 3$ of respondents declared to stay in homes of their relatives and friends which is a comparable result with their purposes of visit connected with VFR. $16 \%$ of students declared to use hospitality exchange and social networking services known as couchsurfing.

Travelling across European counties is easy for Erasmus students due to lack of boarders between the EU countries. The most popular cities amongst interviewed students were London, Madrid and Vienna with over 11, 1\% visiting these cities during their trips abroad. Slightly less popular but still attractive were Paris, Budapest and Helsinki. Most students 
decided to visit the capital city of the country of Erasmus scholarship or neighbouring countries. Moreover, they decided to visit well connected and attractive destinations in the region of the host university. For example, students staying in Spain willingly visited not only Madrid but also Barcelona, Valencia or Granada. Among students who decided to go to Scandinavia a lot of them decided to visit not only the country of reference but also neighbouring countries. For example, most of students staying in Finland decided to visit Stockholm, Tallinn or smaller destinations like Nordkapp, St. Petersburg, Oslo or Vilnius.

\section{Fig. 9. The most nonular tourist cities among Polish Erasmus students.}

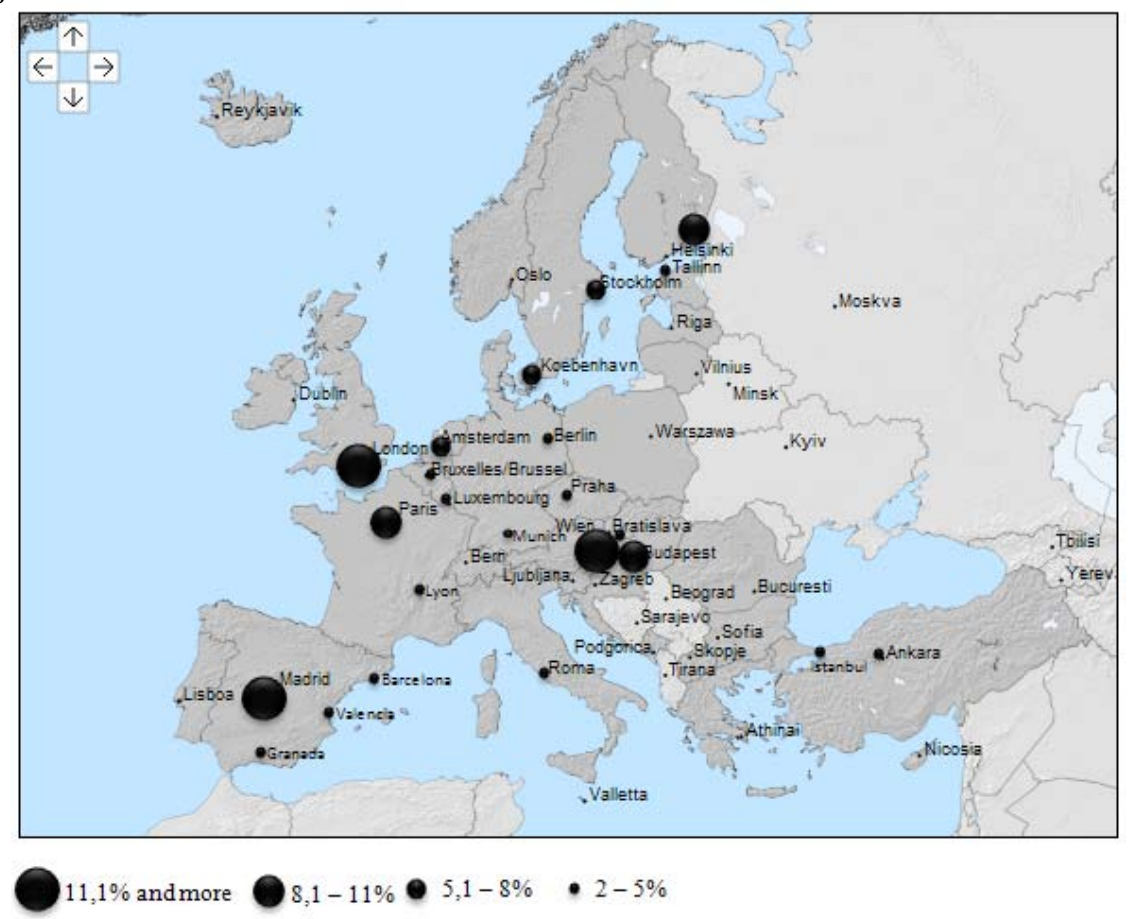

Polish students who took part in the Erasmus programme received on average a monthly scholarship of 400 Euro. This amount is above the average for the academic year 2010/11 which was 250 Euro a month. The Erasmus financial support has to finance any costs of travelling to and staying at the hosting university.

The scholarship money is an incentive to increase students' mobility which is highly limited by the economical development in countries taking part in the Erasmus Programme and therefore by social income.

As the data shows, taking part in travels during the Erasmus programme does not have to mean high financial investments. Interviewed students were careful with their money when spending on travels. More than half (64\%) of interviewed did not spend more than 


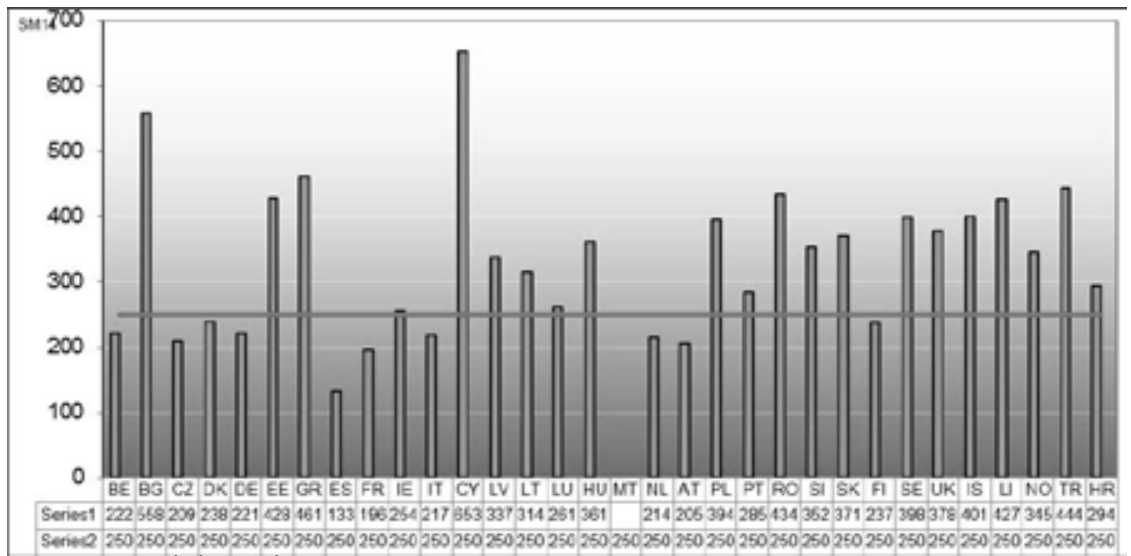

Source: own elaboration

400 Euro during their whole stay at the hosting university and half of them $(34 \%$ of interviewed) did not spend more than 200 Euro. Only 4\% of students taking part in the survey spent over 1001 Euro on travels. The relatively small expenses can result from discounts on public transport or entry tickets to tourist attractions. Moreover, Erasmus

Fig. 10. Approximately how much did you spend for all your travels during your Erasmus shelarship?
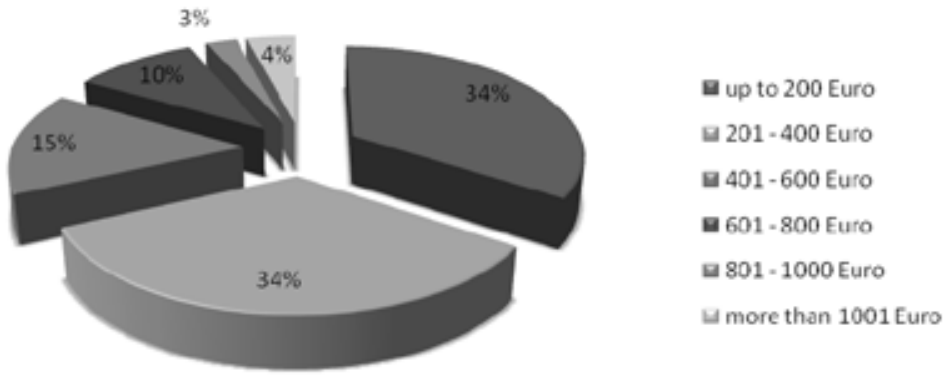

Source: europa.eu/rapid/pressReleasesAction.do?reference...0..., accessed 10/09/2012

students often take advice from students from the hosting university which allows them to plan their spending more rationally.

93\% of students would like to visit the country of Erasmus scholarship again in the future (among them $71 \%$ definitely and $22 \%$ rather). None of the students declared they would definitely not come back to the country of Erasmus scholarship (Fig. 11).

Word of mouth is one of the most efficient ways of advertising. That is why students who are going to recommend the country of their Erasmus scholarship in the future is also very impressive. All together $96 \%$ of students declared to recommend the country for friends and relatives.

Also the students' attitude to the hosting country is very positive; $90 \%$ found the country as a very attractive or attractive. This score is definitely much higher than impressions and experience of an average tourist. During the scholarship students have time to familiarize themselves with the hosting country, they not only become a part of the Erasmus society but also of the local society. They stay among natives, very often learn from them about local habits, language, cuisine etc. which builds strong relationships and changes the perception of the place. Erasmus mobility gives 
an opportunity to get to know the destination from the side which is impossible to be experienced during a typical touristic excursion.

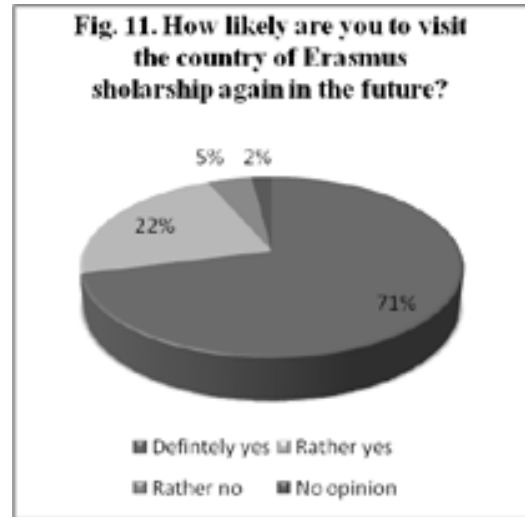

Source: own elaboration.

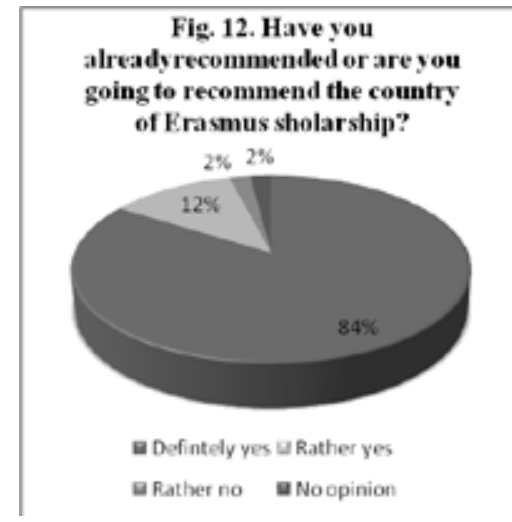

Source: own elaboration.

Europe is a popular tourist destination not only within the Europeans but also worldwide. Tourist attractiveness of European countries is highly rated by Polish Erasmus students. Only $1 \%$ of respondents esteemed the touristic attractiveness of the country they spend Erasmus semester in as very low. The vast majority (90\%) of students rated the touristic attractiveness as high or very high. The consistency of rating demonstrates their positive feeling of the "Erasmus country".

\section{Conclusion}

Excursions during the Erasmus programme realize an important educational and social issue. Spending an academic semester at the host university gives an experience which is unattainable for ordinary tourists. International group excursions are often organized and guided by local students. This results in even stronger European integration. As the research

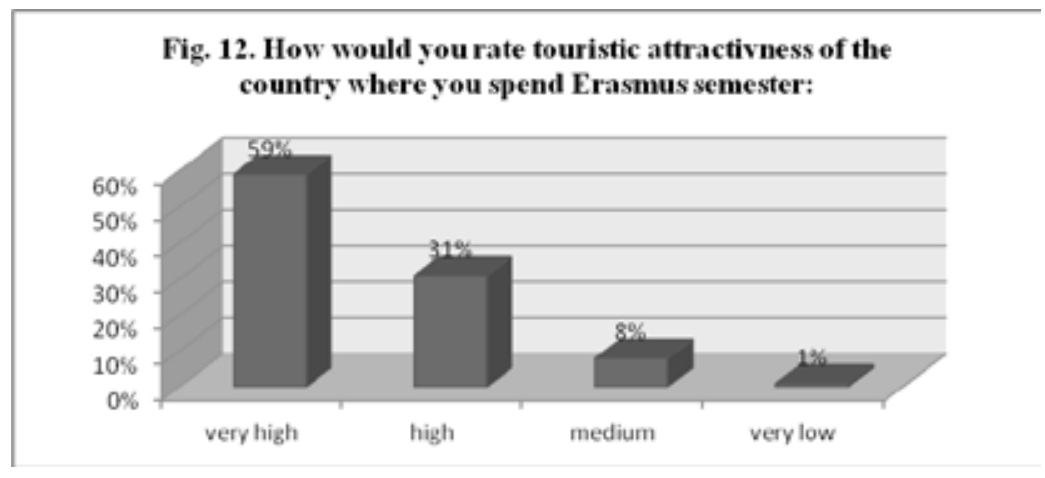

Source: own elaboration

presents, touristic trips during Erasmus semester are not costly which is very important for students' budget. Students who participate in Erasmus programme become a new European generation which means they have high mobility, can speak foreign languages, 
are easy to relate to, tolerant and ready for integration.

\title{
LIST OF REFERENCES
}

1. http://ec.europa.eu/education/lifelong-learning-programme/erasmus_en.htm, accessed 08/09/2012

2. http://ec.europa.eu/education/pub/pdf/higher/erasmus0910_en.pdf, accessed 08/09/2012

3. europa.eu/rapid/pressReleasesAction.do?reference...0..., accessed 10/09/2012

4. http://www.erasmus.org.pl/odnosniki-podstawowe/statystyki, accessed: 08/09/2012.

Стаття: надійшла до редколегї 06.06.2012

прийнята до друку 15.06.2012

\section{МОБІЛЬНІСТЬ ПОЛЬСКИХ СТУДЕНТІВ ПІД ЧАС НАВЧАННЯ ПО ПРОГРАМІ “ЕРАЗМУС” (ЦІЛ, ВИТРАТИ, ОСВІТА)}

\author{
М. Гуралсвіч-Дроздовська, В. Мацієвський \\ Вроилавський Університет бізнесу \\ Вроилав, Польща
}

\begin{abstract}
"Еразмус" - це найбільша програма студентських обмінів у світі. 3 часу заснування у 1997 р., майже 3 млн студентів 333 країн Європи взяли участь у цій програмі. Екскурсії під час навчання по програмі "Еразмус" набули важливої освітньої та соціальної ролі. Перебування впродовж цілого академічного семестру у приймаючому університеті - це досвід, недоступний для звичайних туристів. Студенти, що беруть участь у програмі "Еразмус" - це нове покоління європейців, що означає їхню високу мобільність, вони розмовляють іноземними мовами, легко спілкуються, є толерантними та готовими до співпраці.

Ключові слова: програма “Еразмус", мобільність студентів, екскурсії.
\end{abstract}

\section{МОБИЛЬНОСТЬ ПОЛЬСКИХ СТУДЕНТОВ ВО ВРЕМЯ ОБУЧЕНИЯ ПО ПРОГРАММЕ “ЭРАЗМУС” (ЦЕЛИ, РАСХОДЫ, ОБРАЗОВАНИЕ)}

\author{
М. Гуралевич-Дроздовская, В. Мациевский \\ Вроилавский Университет бизнеса \\ Вроилав, Польша
}

\begin{abstract}
“Эразмус" - это крупнейшая программа студенческих обменов в мире. Со времени основания в 1997 г., почти 3 млн студентов из 33 стран Европы приняли участие в этой программе. Экскурсии во время обучения по программе “Эразмус” приобрели важной образовательной и социальной роли. Пребывание в течение всего академического семестра в принимающем университете - это опыт, недоступный для обычных туристов. Студенты, участвующие в программе "Эразмус" - это новое поколение европейцев, что означает их высокую мобильность, они разговаривают на иностранных языках, легко общаются, является толерантными и готовыми к сотрудничеству.

Ключевые слова: программа “Эразмус”, мобильность студентов, экскурсии.
\end{abstract}

